\title{
COMMENTS
}

\section{THE NEW COMMERCIAL SPEECH AND THE FAIR CREDIT REPORTING ACT}

In 1970, Congress enacted the first significant regulation of the credit reporting industry, ${ }^{1}$ the Fair Gredit Reporting Act (FCRA), ${ }^{2}$ and the scholarly community responded promptly with analysis and commentary. $^{3}$ The FCRA's potential violation of the first amendment, however, received little attention. ${ }^{4}$

In September 1980, in Equifax Services, Inc. $v$. Cohen, ${ }^{5}$ the Supreme Judicial Court of Maine invalidated several sections of the

1 See A Bill to Enable Consumers to Protect Themselves Against Arbitrary, Erroneous, and Malicious Credit Information: Hearings on S. 823 Before the Subcomm. on Financial Institutions of the Senate Comm. on Banking and Currency, 91st Cong., 1st Sess. 2 (1969) (statement of Senator Proxmire) [hereinafter cited as Hearings on S. 823].

2 Fair Credit Reporting Act (FCRA), Pub. L. No. 91-508, $\$ \$ 601-622,84$ Stat. 1114, 1127 (1970) (current version at 15 U.S.C. $\$ \$ 1681-1681$ t (1976 \& Supp. III 1979)).

3 See, e.g., Note, Protecting Privacy in Credit Reporting, 24 STaN. L. REv. 550 (1972) [hereinafter cited as STAN. Note]; Note, Protecting the Subjects of Credit Reports, 80 YALE L.J. 1035 (1971) [hereinafter cited as YaLE Note].

4 See A Bill to Enable Consumers to Protect Themselves Against Arbitrary, Erroneous, and Malicious Credit Information: Hearings on H.R. 16340 Before the Subcomm. on Consumer Affairs of the House Comm. on Banking and Currency, 91st Cong., 2d Sess. 236 (1970) (statement of Lawrence Speiser, Director, Washington Office, American Civil Liberties Union).

Mrs. Sullivan. Now some have argued that placing any restriction on the collection and dissemination of credit or personal data would be in: violation of the constitutional right of free speech, and we would like to have your response to that.

Mr. Speiser. I think that is a frivolous claim. There are all kinds of restrictions placed on commercial enterprises in this country as to what they can say.

The Securities and Exchange Commission, I think, is a good example where they require rather elaborate notifications about the conditions under which securities are now being sold, and very strict controls as to what they can say and how they can say it. These rules do not violate the first amendment.

Similarly, as far back as 1942, the Supreme Court held in Valentine. v. Christensen, [sic] 316 U.S. 52 (1942), that commercial advertising, for example, was not protected by the first amendment.

Id. Mr. Speiser's statement illustrates the extent to which first amendment violations were not an issue.

See generally Hood v. Dun \& Bradstreet, Inc., 486 F.2d 25 (5th Cir. 1973), cert. denied, 415 U.S. 985 (1974); Grove v. Dun \& Bradstreet, Inc., 438 F.2d 433 (3d Cir.), cert. denied, 404 U.S. 898 (1971); Wortham v. Dun \& Bradstreet, Inc., 399 F: Supp. 633 (S.D. Tex. 1975), affd, 537 F.2d 1142 (5th Cir. 1976). By 1976, however, the issue was drawing more attention. See Millstone v. O'HanIon Reports, Inc., 528 F.2d 829 (8th Cir. 1976).

- 420 A.2d 189 (Me. 1980), cert. denied, 101 S. Ct. 1360 (1981). 
Maine Fair Credit Reporting Act (Maine Act), ${ }^{\mathfrak{B}}$ holding that they violated the first amendment of the U.S. Constitution. During the period between the enactment of the FCRA and the invalidation of the Maine Act, the U.S. Supreme Court decided several casesredefining commercial speech and enlarging the first amendment protection afforded such speech. ${ }^{7}$ In its analysis in Equifax, the court discussed a number of these cases. ${ }^{8}$ Because the Maine Act was patterned after the FCRA, the Maine Court's finding raises serious questions about the constitutionality of similar provisions of the FCRA, which impose numerous restrictions and requirements on the speech of credit bureaus in the preparation of consumer credit reports. Requirements include disclosures to the consumer, procedures for ensuring the accuracy of the information reported, and limitations on the information that may be included and on the "users" who may receive reports."

${ }^{6} \mathrm{Me}$. Rev. Stat. ANN. tit. 10, $\$ 1311-1328$ (1980) (Maine Act). The FCRA provides that states may enforce their own consumer reporting legislation to the extent that it is consistent with federal law. 15 U.S.C. $\$ 1681 t$ (1976). In Equifax, the court invalidated, on federal constitutional grounds, two sections of the Maine Act that went beyond the FCRA in regulating consumer reporting. In its analysis, the court used the test enunciated in Central Hudson Gas \& Elec. Corp. v. Public Serv. Comm'n, 447 U.S. 557 (1980), discussed infra at text accompanying notes $35-38$.

First, the court invalidated the sections of the statute forbidding a consumer reporting agency to use, report, or retain in its fles "information which it has reason to believe is . . not relevant to the purpose for which it is sought." ME. Rev. Stat. ANN. tit. 10, $\$ 1314(2), 1314(3)$ (1980). See 420 A.2d at 208. The court declared that these provisions could "infringe upon constitutionally protected commercial speech, since the 'irrelevance' of information does not inevitably, or with strong likelihood, cause it to be deceptive or misleading." $420 \mathrm{~A} .2 \mathrm{~d}$ at 203. The FCRA contains no equivalent restriction.

The court also found unconstitutional $\$ 1314(1)$ of the Maine Act, which forbade preparation or procurement of an investigative consumer report without the subject's consent, because it did not further a substantial governmental interest. Even if it was related to such an interest, however, it did not "directly advance" the interest and was "more extensive than ... necessary to serve it." 420 A.2d at 200. Although the FCRA requires that subjects of investigative consumer reports be notified of their preparation, it does not require consumers' consent. See 15 U.S.C. \$1681d (1976).

Third, the Maine court struck down the provision prohibiting consumer reports from containing specific items of dated information-for example, bankruptcies older than fourteen years or arrest records older than seven years. ME. REv. Stat. ANn. tit. 10, $\$ 1321$ (4) (A) (1980). The court found that this subsection intruded on "constitutionally protected commercial speech" more extensively than necessary to serve the governmental interest. $420 \mathrm{A.2d}$ at 206 . As the court noted, $\$ 1321$ (4)(A) was substantively similar to 15 U.S.C. $\S 1681 \mathrm{c}$, the provision of the FCRA that prohibits the reporting of "obsolete information." 420 A.2d at 206. The Maine court did not purport to pass judgment on any provision of the FCRA; 15 U.S.C. $\$ \$ 1681 \mathrm{c}$ and 1681 , therefore, are still in effect in Maine, despite the invalidation of similar state statutory provisions on federal constitutional grounds.

T See infra text accompanying notes 17-38.

3420 U.S. at 195-209.

${ }^{9}$ See infra text accompanying notes 78-93. 
The first amendment questions raised by Equifax suggest possible constitutional challenges not only to the FCRA but also to the consumer credit reporting regulations of a number of states. In addition to Maine, thirteen states ${ }^{10}$ have enacted laws regulating consumer credit reporting. Ten of these states have restricted the content of consumer credit reports. ${ }^{11}$

This Comment examines the FCRA in light of the new protected status of commercial speech. Part I sets forth the history of the treatment of commercial speech. Part II discusses the appropriateness of classifying consumer reports as commercial speech. After identifying in part III the questionable sections of the FCRA, the Comment in part IV applies the Supreme Court's latest test for commercial speech, articulated in Central Hudson Gas of Electric Corp. v. Public Service Commission, ${ }^{12}$ to the vulnerable sections of the FCRA.

\section{History of the Commercial Speech Doctrine}

The Supreme Court first addressed the issue of first amendment protection for commercial speech in 1942. The question before the Court in that case, Valentine $v$. Chrestensen, ${ }^{13}$ was whether the city of New York could restrain the distribution of advertising handbills

10 Petition for a Writ of Certiorari to the Supreme Judicial Court of the State of Maine at 15, Equifax Services, Inc. v. Cohen, 420 A.2d 189 (Me. 1980), cert. denied, $101 \mathrm{~S}$. Ct. 1360 (1981). The states are: Arizona, ARz. REv. Stat. ANN. $\$ \$ 44-1691$ to -1696 (West Supp. 1980); California, Car. Crv. Cone \$ 1785.1 to 1786.56 (West Supp. 1981); Connecticut, Conn. Gen. Stat. AnN. \$ $\$ 36-431$ to -435 (West 1981); Kansas, KaN. Stat. ANN. $\$ \$ 50-701$ to -722 (1976); Kentucky, Kx. Rev. Stat. $\$ 367.310$ (Supp. 1980); Maryland, MD. CoM. LAW CODE ANN. $\$ \$ 14-1201$ to -1218 (Michie Supp. 1980); Massachusetts, Mass. ANn. Laws ch. 93, $\$ 50-68$ (Michie/Law Co-op 1975 \& Supp. 1981); Montana, Mont. Cones ANN. $\$ 31-3-101$ to -153 (1979); Nevada, Nev. Rev. Stat. $\$ 598 B .130$ (1975); New Hampshire, N.H. REv. Stat. ANN. $\$ \$ 359-B: 1$ to :21 (Supp. 1979); New Mexico, N.M. Stat. ANN. \$\$ 56-3-1 to -8 (1978); New York, N.Y. GEN. Bus. LAw $\$ \$ 380$ to 380-s (McKinney Supp. 1980); Oklahoma, OxLA. Stat. ANN. tit. 24, $\$ \$ 81-85$ (West 1951).

11 Petition For A Writ of Certiorari To the Supreme Judicial Court of the State of Maine at 15, Equifax Services, Inc. v. Coher, 420 A.2d 189 (Me. 1980), cert. denied, 101 S. Ct. 1360 (1981).

Equifax may have implications for other areas of economic regulation as well. See Jackson \& Jeffries, Commercial Speech: Economic Due Process and the First Amendment, 65 VA. L. REv. 1, 3 (1979). Requirements of corrective advertising, see, e.g., Warner-Lambert Co. v. FTC, 562 F.2d 749 (D.C. Cir. 1977), cert. denied, 435 U.S. 950 (1978); Beneficial Corp. v. FTC, 542 F.2d 611 (3d Cir. 1976), or warnings, 15 U.S.C. $\$ 1333$ (1976) (health warnings on cigarette packages), as well as statutes that prohibit the broadcast of cigarette commercials, 15 U.S.C. $\$ 1335$ (1976), all may be vulnerable to first amendment attack under the current treatment of commercial speech.

12447 U.S. 557 (1980). See infra text accompanying notes 35-38.

13316 U.S. 52 (1942). 
as a violation of its sanitary code. The Court's unanimous decision declared that commercial speech warranted no protection. Gities could not interfere unduly with use of the streets to distribute information. The Court found it "equally clear," however, that "the Constitution imposes no such restraints on government as respects purely commercial advertising." 14

The issue of first amendment protection for commercial speech remained well-settled for two decades. The first seeds of change were sown in New York Times Co. v. Sullivan. ${ }^{15}$ Although the Court did not extend first amendment protection to "purely" commercial speech, it did distinguish between noncommercial speech used in a commercial context and commercial speech used in a commercial context. An advertisement in the New York Times, describing events that occurred during a civil rights demonstration in Montgomery, Alabama, resulted in a libel suit against the Times. The Court, in determining the appropriate level of protection for politically motivated advertising containing arguably libelous statements, carefully distinguished it from purely commercial speech:

The publication here was not a "commercial" advertisement in the sense in which the word was used in Chrestensen. It communicated information, expressed opinion, recited grievances, protested claimed abuses, and sought financial support on behalf of a movement whose existence and objectives are matters of the highest public interest and concern. ... That the Times was paid for publishing the advertisement is as immaterial in this connection as is the fact that newspapers and books are sold. ${ }^{16}$

The attack on the wall had begun. Speech appearing in a commercial context but not serving a commercial purpose would not necessarily be dealt with under the Valentine doctrine. The public interest value of the speech, despite its commercial context, determined that it would receive first amendment protection.

The Court further clarified its position concerning commercial speech in Pittsburgh Press Co.v. Pittsburgh Commission on Human Relations. ${ }^{17}$ The Court found that the "Help Wanted" advertisements, which were divided into "Male" or "Female" columns, were "no more than a proposal of possible employment. The advertise-

14 Id. 54.

15376 U.S. 254 (1964).

$16 I d .266$.

17413 U.S. 376 (1973). 
ments are thus classic examples of commercial speech." 18 The Court's ultimate denial of first amendment protection to these advertisements, ${ }^{10}$ however, did not result from their commercial nature. ${ }^{20}$ Rather, the decisive element in this case was that the advertising assisted illegal employment discrimination. ${ }^{21}$ Subsequent commercial speech cases reiterate this principle: a state may prohibit advertising of illegal activity without violating the first amendment. ${ }^{22}$

In Bigelow $v$. Virgina, ${ }^{23}$ the Court took another step toward abandoning the Valentine $v$. Chrestensen doctrine.

The fact that the particular advertisement in appellant's newspaper had commercial aspects or reflected the advertiser's commercial interests did not negate all First Amendment guarantees. The state was not free of all constitutional restraint merely because the advertisement involved sales or "solicitations," . . . or because appellant was paid for printing it, ... or because appellant's motive or the motive of the advertiser may have involved financial gain. ${ }^{24}$

Moreover, the Court reinterpreted the Valentine ban on handbill distribution as a mere time, place, or manner restriction. ${ }^{25}$

The advertisement in Bigelow offered abortion services available in New York. As in New York Times Co. v. Sullivan, the Court found a public interest component in the advertisement that prevented its classification as purely commercial speech, ${ }^{26}$ allowing it again to postpone deciding the treatment of such speech. ${ }^{27}$

$18 \mathrm{Id} .385$.

18 Id. 390-91.

20 Although the Court recognized the possibility that commercial speech may have inherent value making it worthy of more protection than "Chrestensen and its progeny would suggest," it found that argument "unpersuasive in this case." Id. 388 .

21 Id. 389.

22 See infra text accompanying notes $28,33 \& 38$.

23421 U.S. 809 (1975).

24 Id. 818 (citations omitted).

25 Id. 819-20.

26 Id. 822.

27 Regardless of the particular label asserted by the State-whether it calls speech "commercial" or "commercial advertising" or "solicitation"a court may not escape the task of assessing the First Amendment interest at stake and weighing it against the public interest allegedly served by the regulation. The diverse motives, means, and messages of advertising may make speech "commercial" in widely varying degrees. We need not decide here the extent to which constitutional protection is af- 
In 1976, the Court finally confronted the issue whether speech doing no more than proposing a legal commercial transaction should enjoy first amendment protection. In Virginia State Board of Pharmacy v. Virginia Citizens Consumer Council, Inc., ${ }^{28}$ the Court declared:

Our question is whether speech which does "no more than propose a commercial transaction," . . . is so removed from any "exposition of ideas," . . . and from "truth, science, morality, and arts in general, in its diffusion of liberal sentiments on the administration of Government," " ... that it lacks all protection. Our answer is that it is not. $^{29}$

Virginia Pharmacy virtually overruled Valentine v. Chrestensen. The Court's decision rested on the value of commercial speech-in this situation the advertising of prescription drug prices-to the individual consumer ${ }^{30}$ and to society. ${ }^{31}$

Moreover, there is another consideration that suggests that no line between publicly "interesting" or "important" commercial advertising and the opposite kind could ever be drawn. Advertising, however tasteless and excessive it sometimes may seem, is nonetheless dissemination of information as to who is producing and selling what product, for what reason, and at what price. So long as we preserve a predominantly free enterprise economy, the allocation of our resources in large measure will be made through numerous private economic decisions. It is a matter of public interest that those decisions, in the aggregate, be intelligent and well informed. To this end, the free flow of commercial information is indispensable. ${ }^{32}$

The opinion emphasizes the importance of commercial speech in the consumer's decisionmaking process. Because commercial advertis-

forded commercial advertising under all circumstances and in the face of all kinds of regulation.

Id. 826.

28425 U.S. 748 (1976).

29 Id. 762 (citations omitted).

$30 \mathrm{Id} .763$.

31 Id. 764.

32 Id. 765 (citations omitted). The Court here used the expressions "public interest" and "publicly interesting" in apparently contradictory ways. The Court seemed to say that the subject of the advertisement need not be an issue of political or social impact, as in New York Times Co. v. Sullivan and Bigelow v. Virginia, in order to benefit from first amendment protection. Commercial advertising itself has a social value in aiding consumer choices. 
ing has its own value and serves a social purpose, the first amendment protects it. This protection, however, is not absolute. The Court recognized a number of exceptions: restrictions on time, place, and manner; prohibition of false or misleading advertisements; regulations of the broadcast media, and the prohibition of advertisements of illegal activities. ${ }^{33}$

Over the next several years, the Court decided a variety of cases ${ }^{34}$ under the doctrines established in Virginia Pharmacy and earlier cases. In 1979, in Central Hudson Gas \& Electric Corp. v. Public Service Commission, ${ }^{35}$ the Court reexamined in their entirety the doctrines of those cases. The Court again emphasized the value of commercial speech to consumers and to society, ${ }^{36}$ while continuing to indicate that such speech was not entitled to full first amendment protection. ${ }^{37}$ More importantly, the Court articulated a fourpart test to be applied in future commercial speech cases.

At the outset, we must determine whether the expression is protected by the First Amendment. For commercial speech to come within that provision, it at least must concern lawful activity and not be misleading. Next, we ask whether the asserted governmental interest is substantial. If both inquiries yield positive answers, we must determine whether the regulation directly advances the governmental interest asserted, and whether it is not more extensive than is necessary to serve that interest. ${ }^{38}$

${ }^{33}$ Id. 770-73.

34 See, e.g., Friedman v. Rogers, 440 U.S. 1 (1979) (state may bar use of trade names by optometrists); Ohralik v. Ohio State Bar Ass'n, 436 U.S. 447 (1978) (lawyers' in-person solicitations may be prohibited); In re Primus, 436 U.S. 412 (1978) (lawyer's public solicitation of litigation in a public interest setting permissible); Bates v. State Bar, 433 U.S. 350 (1977) (lawyers may advertise).

35447 U.S. 557 (1980). The Public Service Commission's ban on an advertisement that promoted energy use violated Central Hudson's first amendment rights. Applying a four-part test, see infra text accompanying note 38, the Court found the ban too restrictive.

36 Id. 562.

37 Id. 563.

38 Id. 566. The Court applied the four-part Central Hudson test in Metromedia, Inc. v. City of San Diego, 101 S. Ct. 2882 (1981), upholding an ordinance prohibiting outdoor advertising signs to the extent that the ordinance affected commercial speech. Although the ordinance regulated commercial speech protected by Central Hudson, it directly advanced the substantial governmental goals of traffic safety and preservation of the city's aesthetic appearance. Id. 2893. Moreover, the ordinance was not broader than necessary to achieve its purpose. Id. In contrast, the portion of the ordinance regulating more highly protected noncommercial speech violated the first amendment. Id. 2985-86. 
The remainder of this Comment will measure the FCRA against the Central Hudson standard, discussing the following issues: whether consumer reports regulated by the FCRA constitute commercial speech, whether the FCRA's restrictions on this speech implicate the first amendment, and whether the interest balancing required by Central Hudson supports the validity of the FCRA.

\section{Are Consumer Reports Protected Commerclal Speech?}

The FCRA ${ }^{39}$ regulates two types of speech: "consumer reports" and "investigative consumer reports." Consumer reports concern "a consumer's credit worthiness, credit standing, credit capacity, character, general reputation, personal characteristics, or mode of living"; 40 generally, however, they contain prior financial history. Investigative reports contain information "on a consumer's character, general reputation, personal characteristics, or mode of living [that] is obtained through personal interviews with neighbors, friends, or associates of the consumer ..." 41 By their nature, therefore, investigative reports are more subjective and less easily verified than consumer reports.

The FCRA limits the purposes for which either type of report may be prepared. Consumer reporting agencies may furnish reports to users at a consumer's request; in response to a court order; to determine the consumer's eligibility for credit, insurance, employment, or government license or benefit, and to those persons who otherwise have a "legitimate business need" for the information."2

The question whether these reports should be classified as commercial speech has three possible answers. ${ }^{43}$ The first is that consumer reports differ significantly from advertising-the type of speech at issue in nearly all of the Supreme Court's commercial speech decisions-and should be accorded a lower level of protec-

3915 U.S.C. $\$ \$ 1681-1681$ (1976 \& Supp. III 1979).

4015 U.S.C. $\$ 1681 \mathrm{a}(\mathrm{d})$ (1976).

4115 U.S.C. $\$ 1681 \mathrm{a}(\mathrm{e})(1976)$. The term "investigative consumer report" refers to a "consumer report or a portion thereof" in which information is obtained from those sources specified by the statute. Id.

4215 U.S.C. $\$ 1681$ b (1976).

48 In Equifax Services, Inc. v. Cohen, 420 A.2d 189 (Me. 1980), cert. denied, $101 \mathrm{~S}$. Ct. 1360 (1981), the court avoided the question whether the reports regulated by the Maine Act were properly classified as commercial speech. It adopted that classification in the case before it because it considered that framework to have been "fixed by all of the parties, as well as by the adjudication of the Superior Court" 420 A.2d at 195. The court expressed no opinion whether such classification was correct. Id. 
tion. ${ }^{44}$ Second, consumer reports may be entitled to precisely the level of protection given to commercial speech in Central Hudson Gas \& Electric Corp. v. Public Service Commission.45 Third, consumer reports may be entitled to full first amendment protection. This Comment examines the Central Hudson opinion, the courts' treatment of consumer reports, and the policies behind the commercial speech classification to support the conclusion that consumer reports are commercial speech, entitled to the protection set forth in Central Hudson.

\section{A. The Language of Central Hudson}

Many courts have discussed commercial speech ${ }^{46}$ without defining its boundaries clearly. In Central Hudson, the Court set forth a broad definition of commercial speech: "expression related solely to the economic interests of the speaker and its audience." 47 Although the Central Hudson definition did not appear in the Court's most recent commercial speech case, Metromedia, Inc. $v$. City of San Diego, 48 the Court has not repudiated its language in Central Hudson. It is reasonable, therefore, to begin with the Central Hudson definition when considering the appropriate level of first amendment protection for consumer reports.

Consumer reports have attributes falling both inside and outside the Central Hudson definition of commercial speech. Credit reporting agencies are in the business of preparing consumer and investigative reports; the speakers' interests in these reports, there-

"44 The Attorney General of Maine took this position in Equifax. Brief of Defendant/Appellant at 10-15, Equifax Services, Inc. v. Cohen, 420 A.2d 189 (Me. 1980), cert. denied, 101 S. Ct. 1360 (1981).

45447 U.S. 557 (1980). See supra notes 35-38 and accompanying text.

46 See supra notes 13-34 and accompanying text.

47447 U.S. at 561. This broad definition drew fire from Justices Stevens and Brennan, who declared that "it encompasses speech that is entitled to the maximum protection afforded by the First Amendment." Id. 579 (Stevens, J., concurring).

Prior to Central Hudson, commentators offered their own definitions of commercial speech. For the most part these definitions were narrower than the formulation of the Central Hudson Court. For example, Jackson and Jeffries wrote that "[c]ommercial speech" refers to business advertising that does no more than solicit a commercial transaction or state information relevant thereto." Jackson \& Jeffries, supra note 11, at 1 . This definition equates commercial speech with advertising; thus, consumer reports are not included. Another commentator defined commercial speech as "speech referring to a brand name product or service that is not itself protected by the first amendment, issued by a speaker with a financial interest in the sale of the product or service or in the distribution of the speech." Comment, First Amendment Protection for Commercial Advertising: The New Constitutional Doctrine, 44 U. CHr. L. REv. 205, 254 (1976).

$\$ 8101$ S. Ct. 2882 (1981). 
fore, are purely economic. The users' interests are also purely economic when those users are credit grantors and insurance underwriters. When the population of users is expanded to include all persons permitted to receive consumer reports, however, the issue is not so clear-cut. Their interests in the reports may include noneconomic concerns. For example, an employer probably will be concerned about the character of a prospective employee who may be representing his or her business. Similarly, a government official deciding whether to issue a license may wish to consider public well-being in addition to economic efficiency. If the courts decide to treat these potentially subjective decisions as purely economic, ${ }^{49}$ even investigative consumer reports may fall neatly into the Central Hudson definition of commercial speech. If such a rationale is not adopted, however, formalistic application of the Central Hudson language will be less satisfactory. As illustrated above, a report involving only economic interests when addressed to one user may serve noneconomic interests when supplied to another. ${ }^{50}$ These uncertainties call for an examination of the historical treatment of consumer reports and the policies relevant to their classification as a particular type of speech.

\section{B. The Courts' Treatment of Consumer Reports}

Prior to the extension of any first amendment protection to commercial speech, several courts faced the question whether consumer reports should receive the special first amendment protection from libel actions set forth in New York Times Co. v. Sullivan.51 These courts uniformly categorized consumer reports as commercial speech, either explicitly or implicitly, and withheld such protection..$^{52}$ The courts did not discuss commercial speech in detail;

49 In Pittsburgh Press Co. v. Pittsburgh Comm'n on Human Relations, 413 U.S. 376, 385 (1973), the Supreme Court classified help wanted advertisements as "classic examples of commercial speech," perhaps suggesting that the Court views employment decisions as involving only economic interests. See supra note 18 and accompanying text.

50 For example, an investigative report is prepared containing a consumer's financial history and information about his or her character, reputation, and life style. When submitted to a prospective insurer, this report is commercial speech. The insurer will use it only to decide whether to issue an insurance policy. When used by a prospective employer, however, the same report would be more than commercial speech under the Central Hudson test because the user's concerns would be broader than "solely economic."

51376 U.S. 254 (1964).

52 See, e.g., Millstone v. O'Hanlon Reports, Inc., 528 F.2d 829 (8th Cir. 1976); Hood v. Dun \& Bradstreet, Inc., 486 F.2d 25 (5th Cir. 1973), cert. denied, 415 U.S. 985 (1974); Oberman v. Dun \& Bradstreet, Inc., 460 F.2d 1381 
their uniform treatment of consumer reports, however, supports the argument that such reports are appropriately classified as commercial speech.

A 1971 dissent by Justice Douglas also supports this argument:

The language of the First Amendment does not except speech directed at private economic decisionmaking. Certainly such speech could not be regarded as less important than political expression. When immersed in a free flow of commercial information, private sector decisionmaking is at least as effective an institution as are our various governments in furthering the social interest in obtaining the best general allocation of resources. . . .

The financial data circulated by Dun \& Bradstreet, Inc., are part of the fabric of national commercial communication. ${ }^{53}$

In Virginia State Board of Pharmacy v. Virginia Citizens Consumer Council, ${ }^{54}$ the majority opinion cited Justice Douglas's dissent, adopting his free market rationale for the protection of commercial speech..$^{55}$ Although the Court did not need to decide the proper classification of consumer reports, its approval of Justice Douglas's reasoning suggests that it might concur in his conclusion that consumer reports are protected commercial speech.

Reliance on the earlier commercial speech cases, which dealt with advertising, does not necessarily enable one to predict the results of future consumer reporting cases. Moreover, the libel cases classifying consumer reports as commercial speech may have limited precedential value because they were decided prior to the Supreme Court's rethinking of the commercial speech doctrine in Virginia Pharmacy and Central Hudson.56

\section{Policies Underlying the Commercial Speech Classification}

Exploration of the policies underlying the protection of commercial speech is also productive in determining whether consumer

(7th Cir. 1972); Grove v. Dun \& Bradstreet, Inc., 438 F.2d 433 (3d Cir.), cert. denied, 404 U.S. 898 (1971); Kansas Electric Supply Co., Inc. v. Dun \& Bradstreet, Inc., 448 F.2d 647 (10th Cir. 1971), cert. denied, 405 U.S. 1026 (1972); Wortham v. Dun \& Bradstreet, Inc., 399 F. Supp. 633 (S.D. Tex. 1975), aff d, .537 F.2d 1142 (5th Cir. 1976).

53 Dun \& Bradstreet, Inc. v. Grove, 404 U.S. 898, 905-06 (1971) (Douglas, $J$, dissenting from the denial of certiorari) (footnote and citation omitted).

54425 U.S. 748, 765 (1976).

55 Id. 765. See supra text accompanying note 32.

56 See supra text accompanying notes 28-38. 
reports merit such protection. ${ }^{57}$ As early as Pittsburgh Press Co. $\boldsymbol{y}$. Pittsburgh Commission on Human Relations, ${ }^{58}$ the Court intimated that the informational value of commercial speech might require first amendment protection. ${ }^{59}$ The Court made this suggestion explicit in Virginia Pharmacy, emphasizing the importance to individuals and to society of knowing prescription drug prices in order to be able to make informed economic decisions. ${ }^{60}$

As to the particular consumer's interest in the free flow of commercial information, that interest may be as keen, if not keener by far, than his interest in the day's most urgent political debate. ...

Generalizing, society may also have a strong interest in the free flow of commercial information. Even an individual advertisement, though entirely "commercial," may be of general public interest. ${ }^{61}$

Consumer reports, therefore, must be measured against these values: informed decisionmaking ${ }^{62}$ and enriched discussion of an issue of general public interest.

Stores, banks, credit card companies, insurance companies, employers, landlords, and government agencies rely on the information in consumer credit and investigative reports to make a variety of individual decisions. In the Senate hearings on the FCRA, a key witness emphasized the importance of credit to the American economy and of credit reports to the maintenance of the credit system. ${ }^{68}$ This testimony provides a strong argument, under the Court's

57 For general discussions of commercial speech, see Jackson \& Jeffries, supra note 11; Knapp, Commercial Speech, the Federal Trade Commission and the First Amendment, 9 MEM. ST. U.L. REv. 1 (1978); Comment, supra note 47.

58413 U.S. 376,388 (1973).

59 See supra note 20.

60 See supra text accompanying note 32 .

01425 U.S. at 763-64.

62 See Jackson \& Jeffries, supra note 11, for the thesis that the Supreme Court was wrong to extend first amendment protections to commercial speech for this reason.

63 Twenty five years ago consumer credit outstanding was 5.7 billion dollars. Today it is 110 billion. Through the use of credit the average American consumer has been able to enjoy some of the comforts of life as well as the necessities. Credit is crucial for the poor.

The credit reporting agency is a vital link in the operation of this rapidly growing consumer credit industry. The creditor needs the potential customer's credit history in order that he can properly assess any risk which might be involved in extending credit. The consumer also benefits when he can secure credit promptly without undue red tape.

Hearings on S. 823, supra note 1, at IIa (statement of Virginia H. Knauer, Special Assistant to the President for Consumer Affairs). 
rationale in Virginia Pharmacy, for extending first amendment protection to consumer reports.

On the other hand, consumer reports contribute neither to society's discussion of a public issue ${ }^{64}$ nor to its enlightenment .about the functioning of the economic system..$^{65}$ Consumer reports instead are limited to small select audiences, usually paying users. ${ }^{66}$ In Equifax Services, Inc. v. Cohen, ${ }^{67}$ the Attorney General of Maine argued that consumer reports, which reach only a limited audience, should be denied the protection given to commercial advertising, which reaches a larger, more general audience. ${ }^{68}$ In the consumer report libel cases decided prior to Virginia Pharmacy, the courts relied on this argument. ${ }^{69}$

64 The Court discussed this rationale in Bigelow v. Virginia, 421 U.S. 809, .822 (1975). In Millstone v. O'Hanlon Reports, Inc., 528 F.2d 829 (8th Cir. 1976), the court found that "by the test enunciated in Bigelow, consumer credit reports are not protected speech for which under the First Amendment 'Congress shall make no law ...." Id. 833.

65 The Court discussed this rationale in Virginia Pharmacy, 425 U.S. 748 (1976), declaring that free advertising allowed consumers to make informed decisions and that those decisions in the aggregate provided an appropriate allocation of resources. "To this end, the free flow of commercial information is indispensable. . . . And if it is indispensable to the proper allocation of resources in a free enterprise system, it is also indispensable to the formation of intelligent opinions as to how that system ought to be regulated or altered." Id. 765 (citations -omitted). For criticism of this proposition, see Jackson \& Jeffries, supra note 11.

B6 Prior to the FCRA, availability of access to consumer reports created two sorts of problems. First, credit bureaus failed to provide adequate safeguards to ensure that only users with legitimate business reasons could avail themselves of the information. See Hearings on S.823, supra note 1, at 67-68 (statement of William F. Willier). Second, credit bureaus often made it impossible for a consumer to see his or her own file or to gain knowledge of its contents. See Hearings on S. 823, supra note 1 , at 84-85 (statement of Professor Alan F. Westin).

67420 A.2d 189 (Me. 1980), cert. denied, 101 S. Ct. 1360 (1981).

68 Brief of Defendant/Appellant at 13-15, Equifax Services, Inc. v. Cohen, 420 A.2d 189 (Me. 1980), cert. denied, 101 S. Ct. 1360 (1981).

69 For example, in Grove v. Dun \& Bradstreet, 438 F.2d 433 (3d Cir.), cert. -denied, 404 U.S. 898 (1971), the court relied on the confidentiality of consumer reports in its decision to deny them first amendment protection. Although the court found that for first amendment purposes no principled distinction could be made " "between radio and television on the one hand and the press on the other," id. 437 (quoting Rosenbloom v. Metromedia, Inc., 415 F.2d 892, 895 (3d Cir. 1969), aff d, 403 U.S. 29 (1971)), it declared:

We find such a distinction patent, however, between a publication which disseminates news for public consumption and one which provides specialized information to a selective, finite audience. To be sure, defendant's publication is not held out for public consumption.

Id. The contract at issue in Grove required the user of the consumer report to hold its information in "strict confidence." Id. The court seized on this requirement, noting that the reporting agency had not attempted any public dissemination of information. Id. Accord Hood v. Dun \& Bradstreet, Inc., 486 F.2d 25, 29 (5th Cir. 1973); Wortham v. Dun \& Bradstreet, Inc., 399 F. Supp. 633, 639 n.2 (S.D. Tex. 1975), affd, 537 F.2d 1142 (5th Cir. 1976).

These cases, however, concerned the applicability of the malice standard for libel, see New York Times Co. v. Sullivan, 376 U.S. 254 (1964), to consumer 
An argument that makes first amendment protection dependent on audience size, however, is not persuasive in other contexts. Street corner soapbox orators or religious zealots seeking converts may be ignored; this lack of audience does not justify treating their speech as unworthy of first amendment protection. One theory underlying the first amendment is that all speech, whether true or false, wise or foolish, heard or ignored, contributes to the marketplace of ideas from which truth will emerge. ${ }^{70}$ Indeed, the speech with the smallest audience may be in need of the greatest protection because it is most subject to majoritarian attack.

In extending first amendment protection to commercial speech, the Court has recognized the value of that speech to its audience; that is, its utility. For example, in Virginia Pharmacy, the Court noted both the value of the speech to a small audience, even a single individual, ${ }^{71}$ and its value to society at large. ${ }^{72}$ Utility, therefore, exists quite apart from audience size.

A hypothetical example illustrates this point. A producer of popular records who wishes to advertise the release of a new album can purchase advertising space in a general interest publication with a large circulation or in Rolling Stone with a smaller circulation. Although more people will see the advertisement in the first publication, it will be of only passing interest to most of them; that is, of low utility. For most readers of Rolling Stone, however, the advertisement will be of great interest. In this example, the speech has much greater effect and succeeds in its purpose by reaching a smaller but more receptive audience. The relationship of a consumer report to its audience is analogous. Society in general has little, if any, interest in the credit history of an individual credit applicant. In the public forum, the speech is of low utility. To credit grantors, however, the information is vital for informed decisionmaking.

credit reports. The courts relied on the most recent in the New York Times line of cases, Rosenbloom v. Metromedia, Inc., 403 U.S. 29 (1971), which stressed a public interest issue rather than the public official distinction of New York Times. This line of reasoning was abandoned in Gertz v. Robert Welch, Inc., 418 U.S. 323 (1974). The courts' discussions in these consumer report libel cases, therefore, in noting that the information was not publicly disseminated, may have meant only that the speech contained no public interest component; thus, it did not deserve Rosenbloom's protection from libel prosecutions.

70 "It is the purpose of the First Amendment to preserve an uninhibited marketplace of ideas in which truth will ultimately prevail ...." Red Lion Broadcasting Co. v. FCC, 395 U.S. 367, 390 (1969). See generally First National Bank v. Bellotti, 435 U.S. 765, 766-77 (1978); Thornhill v. Alabama, 310 U.S. 88, 101-02 (1940); Abrams v. United States, 250 U.S. 616, 630 (1919) (Holmes, J., dissenting).

71425 U.S. at 763.

72 Id. 764. 
Although the audience is limited, the value of the speech is very high. Such high utility constitutes a strong argument for applying to consumer reports the same standard of protection afforded other forms of commercial speech. ${ }^{73}$

\section{Summary}

Consumer reports in some of their incarnations may not fit precisely into the Central Hudson definition of commercial speech; for the most part, however, they fall within the spirit of the Court's broad definition. ${ }^{74}$ The treatment given consumer reports in the libel cases, which uniformly treated those reports as commercial speech, adds some support to this conclusion. Moreover, the policies underlying the extension of first amendment protection to commercial advertising suggest that no distinction can be drawn between the protection afforded advertising and that which should be afforded consumer reports. The precise form of this protection is discussed in greater detail in part IV of this Comment.

\section{Fair Credit Reporting Act Restrictions on Speech}

A closer look at the FCRA's restrictions on speech will identify the provisions that may pose first amendment problems. The statute imposes three types of requirements: disclosure requirements, ${ }^{75}$ procedures to ensure accuracy, ${ }^{76}$ and limitations on the content of reports and the persons entitled to receive them. ${ }^{77}$

73 This Comment contends that either of the rationales presented in Virginia Pharmacy, see supra text accompanying notes 61,71-72, justifies affording first amendment protection. Both need not be present.

74 An alternative to equating consumer reports with other forms of commercial speech is to label them "private commercial speech" less deserving of constitutional protection than public advertising. In Central Hudson, the Court declared that "[t]he First Amendment's concern for commercial speech is based on the informational function of advertising." 447 U.S. at 563; see also First National Bank v. Bellotti, 435 U.S. 765,782 n.18, 783 (noting the "informational purpose" of the first amendment and its "role in affording the public access to discussion, debate, and the dissemination of information and ideas"). This concept of "informational function," however, may involve the edification of a single listener as well as enlightenment of the general public. In Virginia Pharmacy, the Court noted that prescription drug advertising served both types of informational functions. See supra text accompanying note 61 . If the Court chooses to consider public exposure the most significant justification for the protection of commercial speech, however, it may be willing to create a category of "private" commercial speech that can be regulated more freely.

7515 U.S.C. $\$ 1681 \mathrm{~d}, 1681 \mathrm{~g}, 1681 \mathrm{~m}$ (1976).

7615 U.S.C. $\$ 1681$ e, 1681i, 1681k, $1681 l$ (1976).

7715 U.S.C. $\$ 1681 \mathrm{~b}, 1681 \mathrm{c}$ (1976 \& Supp. III 1979). 
The disclosure provisions require notification to a consumer when an investigative report has been provided. At the consumer's. request, the user of the report must disclose its "nature and scope." 78 The consumer also may require the credit bureau to disclose the nature and substance of the information in the consumer's file, most of the sources of this information, and the names of its recipients. ${ }^{70}$ When a user relies on a consumer report to deny or to increase the cost of credit or insurance, or to deny employment, the user must notify the consumer of the existence and source of the adverse report. ${ }^{80}$ These provisions do not abridge speech; rather, they impose collateral restrictions on its exercise. Of the provisions of the FCRA implicating first amendment concerns, however, these notice requirements are the least troublesome. In Buckley $v$. Valeo, ${ }^{81}$ the Court approved the significant public disclosure requirements of the Federal Election Campaign Act ${ }^{82}$ in the context of even more highly protected speech: the political dialogue at the heart of the first amendment. ${ }^{83}$ The Court upheld these requirements despite their strong potential for "chilling" the exercise of first amendment rights. The Court has not found "chilling" to be a problem in commercial speech cases. It considers commercial speech "a hardy breed of expression that is not 'particularly susceptible to being crushed by overbroad regulation." 84 The disclosure requirements of the FCRA, which limit disclosure to the consumer having a strong and direct interest in learning what has been reported about him or her, carry little danger of "chilling" the speaker's exercise of first amendment rights and should present no first amendment problems. ${ }^{85}$

The procedures requiring accuracy also are not likely to raise first amendment problems. They provide for the reinvestigation,

7815 U.S.C. $\$ 1681 d(1976)$.

79 15 U.S.C. \$1681g (1976). "[S]ources of information acquired solely for use in preparing an investigative consumer report and actually used for no other purpose need not be disclosed ...." Id. Names of recipients using the report for employment purposes during two years preceding the request must be disclosed; names of other recipients during six months preceding the request must be disclosed. Id.

8015 U.S.C. $\$ 1681 \mathrm{~m}(\mathrm{a})(1976)$.

81424 U.S. 1 (1976) (per curiam).

82 2 U.S.C. $\$ 431-456$ (1976 \& Supp. III 1979).

83 See T. Emerson, The System of Fremod of Expresston (1970); A. Meiktejofn, Free Speech and Its Relation to Sel,-Governmont (1948).

84 Central Hudson Gas \& Elec. Corp. v. Public Serv. Comm'n, 447 U.S. 557, 564 n.6 (1980) (quoting Bates v. State Bar, 433 U.S. 350, 381 (1977)). See infra note 95 .

85 Arguably, however, the governmental interest in safeguarding the electoral process involved in Buckley is stronger than the interests protected by the FCRA. These interests are discussed in detail infra at text accompanying notes 97-153. 
and correction when necessary, of information challenged by consumers. If the dispute cannot be resolved to the consumer's satisfaction, the credit bureau must include the consumer's side of the story in its reports. At the consumer's request, the bureau must notify prior users of the corrections. ${ }^{86}$ Public record information must be kept up to date ${ }^{87}$ and adverse information verified if used in later reports. ${ }^{88}$ All of these requirements are means of ensuring that the credit bureau's information will be accurate. The Court made explicit that false and misleading commercial speech is excluded from first amendment protection in Virginia State Board of Pharmacy v. Virginia Citizens Consumer Council, Inc.; ${ }^{89}$ it reiterated this principle in Central Hudson Gas \& Electric Corp. v. Public Service Commission. ${ }^{90}$ Because the FGRA's accuracy provisions limit only false or misleading speech, they are likely to withstand a first amendment challenge.

The provisions limiting the information that may be included in consumer reports and the users to whom such reports may be provided, ${ }^{91}$ however, raise serious first amendment issues. Limiting the

8615 U.S.C. $\$ 1681 i(1976)$.

8715 U.S.C. $\$ 1681 \mathrm{k}(2)(1976)$.

8815 U.S.C. $\$ 1681 l$ (1976).

s9 425 U.S. 748, 771 (1976).

90447 U.S. 557, 566 ( 1980 ).

91 A consumer reporting agency may furnish a consumer report under the following circumstances and no other:

(1) In response to the order of a court having jurisdiction to issue such an order.

(2) In accordance with the written instructions of the consumer to whom it relates.

(3) To a person which it has reason to believe-

(A) intends to use the information in connection with a credit transaction involving the consumer on whom the information is to be furnished and involving the extension of credit to, or review or collection of an account of, the consumer; or

(B) intends to use the information for employment purposes; or

(C) intends to use the information in connection with the underwriting of insurance involving the consumer; or

(D) intends to use the information in connection with a determination of the consumer's eligibility for a license or other benefit granted by a governmental instrumentality required by law to consider an applicant's financial responsibility or status; or

(E) otherwise has a legitimate business need for the information in connection with a business transaction involving the consumer.

15 U.S.C. $\$ 1681 b$ (1976).

(a) Except as authorized under subsection (b) of this section, no consumer reporting agency may make any consumer report containing any of the following items of information: 
audience that may receive protected speech is a severe restriction that does not fall within any of the recognized exceptions to first amendment protection of commercial speech. ${ }^{92}$ The restriction on content and audience must be measured against the Central Hudson test.

The FCRA also prohibits inclusion of "obsolete" information in consumer reports. Obsolete information is defined to include: bankruptcies older than ten years; suits and judgments older than the longer of seven years or the statute of limitations; tax liens paid more than seven years before; records of arrest, indictment, or conviction older than seven years, and any other adverse information older than seven years. ${ }^{93}$ These réstrictions pose the most serious affront to first amendment values because they are content-specific prior restraints. Futhermore, they ban the use of certain kinds of public record information.94 Although the doctrine of prior restraint may not be applicable to commercial speech, ${ }^{, 5}$ and although

(1) cases under title 11 or under the Bankruptcy Act that, from the date of entry of the order for relief or the date of adjudication, as the case may be, antedate the report by more than 10 years.

(2) Suits and judgments which, from date of entry, antedate the report by more than seven years or until the governing statute of limitations has expired, whichever is the longer period.

(3) Paid tax liens which, from date of payment, antedate the report by more than seven years.

(4) Accounts placed for collection or charged to profit and loss which antedate the report by more than seven years.

(5) Records of arrest, indictment, or conviction of crime which, from date of disposition, release, or parole, antedate the report by more than seven years.

(6) Any other adverse item of information which antedates the report by more than seven years.

(b) The provisions of subsection (a) of this section are not applicable in the case of any consumer credit report to be used in connection with-

(1) a credit transaction involving, or which may reasonably be expected to involve, a principal amount of $\$ 50,000$ or more;

(2) the underwriting of life insurance involving, or which may reasonably be expected to involve, a face amount of $\$ 50,000$ or more; or

(3) the employment of any individual at an annual salary which equals, or which may reasonably be expected to equal $\$ 20,000$, or more.

15 U.S.C. \$1681c (1976 \& Supp. III 1979).

92 See supra note 33 and accompanying text.

9315 U.S.C. \$1681c (1976 \& Supp. III 1979).

94 Cf. Cox Broadcasting Corp. v. Cohn, 420 U.S. 469 (1975) (a state may not impose sanctions on the accurate publication of a rape victim's name obtained from judicial records that are open to public inspection).

95 Even if the differences [among types of speech] do not justify the conclusion that commercial speech is valueless, and thus subject to complete suppression by the State, they nonetheless suggest that a different degree of protection is necessary to insure that the flow of truthful and 
a content-specific inquiry may be required in order to prevent dissemination of false and misleading information, ${ }^{96}$ a total ban on such a wide variety of information demands a close examination. The next part of this Comment, which applies the Central Hudson test to these questionable provisions of the FCRA, will consider in detail these apparent affronts to first amendment values.

\section{Central Hudson ApPLIED}

In Bigelow v. Virginia, ${ }^{97}$ the Court emphasized the necessity of looking beyond labels to determine the appropriate level of first amendment protection for speech in the commercial realm. "Regardless of the particular label asserted by the State-whether it calls speech 'commercial' or 'commercial advertising' or 'solicitation'-a court may not escape the task of assessing the First Amendment interest at stake and weighing it against the public interest allegedly served by the regulation." 98 Central Hudson Gas \& Electric Corp. v. Public Service Commission 99 restates this proposition: "The protection available for particular commercial expression turns on the nature both of the expression and of the governmental interests. served by its regulation." 100

The Court thus has determined that first amendment analysisof commercial speech questions involves a balancing test. The fourpart ${ }^{101}$ test of Central Hudson provides a framework for this process. The first part of the test maintains the long-standing exclusion of misleading information or information advertising an illegal transaction from first amendment protection. ${ }^{102}$ The second and third parts.

legitimate commercial information is unimpaired. The truth of commercial speech, for example, may be more easily verifiable by its disseminator than, let us say, news reporting or political commentary, in that ordinarily the advertiser seeks to disseminate information about a specific product or service that he himself provides and presumably knows more about than anyone else. Also, commercial speech may be more durable than other kinds. Since advertising is the sine qua non of commercial profits, there is little likelihood of its being chilled by proper regulation and foregone entirely.

... [These attributes] may ... make inapplicable the prohibition against prior restraints.

Virginia Pharmacy, 425 U.S. at 771 n.24.

${ }^{96}$ Central Hudson, 447 U.S. at 563-64 \& n.6.

97421 U.S. 809 (1975).

88 Id. 826.

89447 U.S. 557 (1980).

100 Id. 563.

101 See supra text accompanying note 38 .

102 See supra notes $22,33 \& 89$ and accompanying text. 
of the test seek to determine whether the governmental interest is "substantial" and directly advanced by the regulation in question. ${ }^{103}$ The fourth part of the test requires a determination whether the regulation is more restrictive than necessary to serve the governmental interest. The remainder of this part of the Comment will apply the Central Hudson test to the two problematic sections of the FCRA: the limitation on parties who may receive credit information ${ }^{104}$ and the prohibition on the use of dated information in credit reports. ${ }^{105}$

A. "For commercial speech to come within [the shelter of first amendment protection] it at least must concern lawful activity and not be misleading." 108

Consumer credit and investigative reports do not propose illegal transactions; ${ }^{107}$ thus, they satisfy the "lawful activity" requirement of this part of the Central Hudson test. The limitation on parties who may receive credit information also bears no relationship to

103 The level of protection afforded commercial speech has been set forth only in terms of a balancing test. The protection is related to the nature or value of the speech and can be outweighed by an interest that must be at least "substantial."

The precise meaning of a "substantial" interest is not defined, either in Central Hudson or in the cases applying the Central Hudson standard. In Record Revolution No. 6, Inc. v. City of Parma, 638 F.2d 916 (6th Cir. 1980), vacated and remanded, $101 \mathrm{~S}$. C. 2998 (1981), the court summarily assumed that the interest was substantial and that the regulation in question directly advanced that interest. "The regulatory interest of Parma, Lakewood and North Olmstead in stopping drug abuse is plainly substantial. Also, the broad regulation would seem to advance this interest directly, though its effectiveness may be questioned." Id. 936.

The New York Court of Appeals applied the same kind of summary analysis in Koffler v. Joint Bar Ass'n, 51 N.Y.2d 140, 412 N.E.2d 927, 432 N.Y.S.2d 872 (1980), cert. denied, $101 \mathrm{~S}$. Ct. 1733 (1981). The court perhaps found more extensive analysis unnecessary because it knew that the challenged regulations would fail the fourth part of the Central Hudson test.

104 See supra note 91.

105 See supra note 91.

100447 U.S. at 566.

107 Legislation other than credit reporting legislation may make illegal the use of certain types of information for specified purposes. In Equifax Services, Inc. v. Cohen, 420 A.2d 189 (Me. 1980), cert. denied, $101 \mathrm{~S}$. Ct. 1360 (1981), the court noted that "the Maine Human Rights Act prohibits discrimination based solely upon age, sex, race, religion, color, physical or mental handicap, ancestry, or national origin in the specific areas of credit extension, employment, housing and public accommodations." 420 A.2d at 203. The Attorney General argued that the Maine Act's provisions prohibiting inclusion of the same information in credit reports were directed toward commercial speech that "relates to illegal activity" and is not entitled to first amendment protection. Brief of Defendant/Appellant at 25-27, Equifax Services, Inc. v. Cohen, 420 A.2d 189 (Me. 1980), cert. denied, 101 S. Ct. 1360 (1981). The court rejected this argument, refusing to presume that recipients of consumer reports would use information illegally simply because they had access to it. 420 A.2d at 205. 
either part of this test. Dated information in consumer reports, however, conceivably could mislead potential credit grantors. The Maine court failed to find adequate support for the presumption that dated information was "more likely to deceive the public than to inform it" 108 in the legislative history of the FCRA. ${ }^{109}$

Two hypothetical situations illustrate the tensions underlying section 1681c, the provision prohibiting use of dated information. First, assume that eleven years ago $\mathrm{Mr}$. Jones was adjudged a bankrupt, the result of unwise and immature decisions. Today he is financially prudent. Second, assume that eight years ago Mr. Smith was convicted of child molesting while employed as a school bus driver. ${ }^{110}$ Today, a school personnel officer is considering hiring him as a bus driver.

These two hypothetical situations provoke different kinds of concerns. In Jones's case, the policy of granting a bankrupt a fresh start, combined with the passage of time, make reliance on this dated information more likely to mislead than to inform a potential credit grantor, and the information should be deleted. In Smith's case, it seems more desirable for the decisionmaker to be able to weigh all relevant information.

Congress had to grapple with these conflicting concerns in considering the FCRA.111

Creditors obviously have a right to know if a person has had trouble in paying his bills. At the same time it is unfair to burden a consumer for life with a bad credit record if he has improved his performance. The Associated Credit Bureaus has [sic] recognized this problem and had proposed voluntary guidelines to its members to the effect that ad-

108 Central Hudson, 447 U.S. at 563.

109 Equifax Services, Inc. v. Cohen, 420 A.2d 189, 206 (Me. 1980), cert. denied, 101 S. Ct. 1360 (1981).

In Friedman v. Rogers, 440 U.S. 1 (1979), the Court found the use of trade names by optometrists to be misleading. To support this finding, the Court relied heavily on the legislative history of a Texas statute prohibiting the use of such names. Id. 13-14. In Ohralik v. Ohio State Bar Ass'n, 436 U.S. 447 (1978), a Federal Trade Commission report concerning the abuses of direct selling provided partial support for the Court's decision that in-person solicitations by lawyers were likely to foster misrepresentations. Id. 464. Apparently the Court considers legislative findings significant in determining whether advertising is misleading.

110 This hypothetical situation was suggested by William Folkes, attorney for Equifax Services, Inc., Atlanta, Georgia, during a telephone interview in February, 1981.

Conviction records less than seven years old may be included in investigative reports. 15 U.S.C. $\$ 1681 c(a)(5)$ (1976).

111 Section $1681 \mathrm{c}$ represents Congress's effort to balance these conflicting values. See supra note 91 for the text of this provision. If a credit transaction, life insurance policy value, or potential salary exceed specified dollar amounts, credit reports need not exclude "obsolete" information. 15 U.S.C. \$1681c(b) (1976). 
verse information not be reported if it is older than 7 years or 14 years in the case of bankruptcies. ${ }^{112}$

The credit industry itself recognized the difficulties in balancing these two conflicting concerns and suggested the original sevenand fourteen-year limitations on the use of dated information. "The industry has voluntarily cooperated with the committee in developing sound and workable legislation which accomplishes the objectives without imposing unduly restrictive requirements on the industry." 113 This suggestion and the industry's attempt at selfregulation may indicate that the credit industry itself believes that dated information is "misleading."

Congress was concerned primarily about the "relevance" 114 of dated information. Although a correlation between information that is irrelevant and information that is misleading may exist, it is not clear that Congress's concern in banning dated information stemmed primarily from a belief that dated information is presumptively misleading. ${ }^{115}$ Because neither the examples nor the legislative history clearly support the proposition that dated information in consumer reports is "more likely to deceive . . . than to inform," 118 exclusion of this information from all first amendment protection seems inappropriate. ${ }^{117}$

B. "Next, we ask whether the asserted governmental interest is sibstantial ... [and] whether the regulation directly advances the governmental interest asserted ...." 118

The Senate Subcommittee on Financial Institutions devoted five days of hearings and 562 pages of testimony to demonstrating the need for the FCRA and explaining its purpose. ${ }^{119}$ The first

112115 Cong. REc. 33,410 (1969) (remarks of Senator Proxmire).

${ }^{113} \mathrm{Id}$. The credit industry undertook this balancing of interests before first amendment protection had been extended to commercial speech.

114 Senator Proxmire, in presenting the FCRA to the Senate, characterized it as a response to three recurring complaints about consumer reports: their lack of accuracy, relevance, and confidentiality. Senator Proxmire considered the restriction on the use of dated information a response to the problem of irrelevance. See 115 Cong. Rec. 2414-15 (1969).

115 One item of testimony at the Senate hearings on the FCRA, however, indicated that obsolete information is inherently misleading, painting an inaccurate picture of a person whose financial habits have changed. See Hearings on S. 823, supra note 1, at 110 (statement of Wendell G. Lindsay, Jr., on behalf of Louisiana Consumers' League).

116 Central Hudson, 447 U.S. at 563.

117 Cf. Friedman v. Rogers, 440 U.S. 1, 13-15 (1979) (noting the Texas legislature's specific finding that optometrists' use of tradenames was inherently misleading and accepting this finding).

118447 U.S, at 566 .

119 See Hearings on S. 823, supra note 1. 
section of the FCRA sets forth the congressional findings and the purposes of the legislation. ${ }^{120}$ Like much of the testimony before the committee, this section emphasizes the need to guarantee accuracy, privacy, and relevance. The issue whether these interests are sufficiently substantial to sustain a regulation that prohibits the use of one kind of information or that limits the parties who may receive consumer reports, therefore, must be addressed.

Section 1681c's prohibition primarily reaches dated public record information that is presumptively accurate. Prohibiting the use of this information, therefore, does not advance the governmental interest in accuracy. Also embraced by the prohibition, however, is "any other adverse item of information" more than seven years old. ${ }^{121}$ Prohibiting use of this kind of information does advance the accuracy interest. Dated information not supported by a public document will be more difficult to verify and to update and therefore more difficult for the credit applicant to refute successfully.

Accuracy, however, is not the only value the FCRA seeks to protect. Hearings before the Senate subcommittee emphasized another governmental interest: privacy. The testimony reprinted a Georgetown Law Journal Note discussing the concept of privacy as applied to consumer reports.

The right to privacy has been defined as a legal concept of the power of an individual to determine the extent to which another individual or group may obtain his ideas, writings, or other indicia of his personality; obtain or re-

120 (a) The Congress makes the following findings:

(1) The banking system is dependent upon fair and accurate credit reporting. Inaccurate credit reports directly impair the efficiency of the banking system, and unfair credit reporting methods undermine the public confidence which is essential to the continued functioning of the banking system.

(2) An elaborate mechanism has been developed for investigating and evaluating the credit worthiness, credit standing, credit capacity, character, and general reputation of consumers.

(3) Consumer reporting agencies have assumed a vital role in assembling and evaluating consumer credit and other information on consumers.

(4) There is a need to insure that consumer reporting agencies exercise their grave responsibilities with fairness, impartiality, and a respect for the consumer's right to privacy.

(b) It is the purpose of this subchapter to require that consumer reporting agencies adopt reasonable procedures for meeting the needs of commerce for consumer credit, personnel, insurance, and other information in a manner which is fair and equitable to the consumer, with regard to the confidentiality, accuracy, relevancy, and proper utilization of such information in accordance with the requirements of this subchapter.

15 U.S.C. \$1681 (1976).

12115 U.S.C. $\$ 1681 \mathrm{c}(6)$ (1976). 
veal information about him; and intrude into his life space. Inherent in this definition are two significant problems, both of which arise in a credit investigation context. One is the release of information to persons who have no legitimate business interest in it; the other is the collection of information of a highly personal nature. These problems have no relation to the truth or falsity of a report, but are intimately tied to the concept of a right to privacy. ${ }^{122}$

An essential ingredient of privacy is the ability to control information about oneself. Another article cited in the hearings ${ }^{123}$ emphasized this control: Privacy is not simply an absence of information about us in the minds of others; rather it is the control we have over information about ourselves. ${ }^{124}$

The FCRA attempts to balance the consumer's interest and the massive credit reporting industry's interest; it helps the individual consumer to control the recipients of information and the portion of his or her life that may be scrutinized.125 "Whenever a private organization is able to exercise substantial power over an individual, public regulation has generally followed to insure that the power is. exercised fairly." 120

The FCRA represents Congress's determination of the appropriate balance between the credit industry's need for information and the individual's right to privacy. ${ }^{128}$

A creditor does not have an absolute right to obtain details on any and all aspects of a person's private life merely because he has applied for credit, even if the creditor can demonstrate some vague and tenuous relationship between the information and the decision as to whether or not to grant credit. At some point the individual's right to privacy takes precedent [sic] over the creditor's right to obtain information. ${ }^{128}$

122 Note, Credit Investigations and the Right to Privacy: Quest for a Remedy, 57 GEo. L.J. 509 (1969), quoted in Hearings on S. 823, supra note 1, at 456, 470 (footnotes omitted).

123 Hearings on S. 823, supra note 1, at 38-39 (statement of John Caemmerer, citing Fried, Privacy, 77 YATE L.J. 475, 482 (1968)).

124 Fried, supra note 123, at 482 (emphasis in original).

125 Stan. Note, supra note 3 , at 556.

126 Hearings on S. 823, supra note 1, at 2 (statement of Senator Proxmire).

${ }^{127}$ But see Comment, The Fair Credit Reporting Act Amendments: Enforcement of the Legislative Trust?, 45 Mrss. L.J. 95, 107-08 (1974) (arguing that the many changes made in the original bill as it traveled through Congress resulted in legislation that failed to reflect the purposes of either the House or the Senate).

128115 Conc. Rec. 2413 (1969) (remarks of Senator Proxmire). 
The Supreme Court, in a variety of contexts, also has addressed the issue of individuals' rights to privacy. For example, an individual's privacy interest in procreation decisions ${ }^{129}$ is of a constitutional dimension, as is the fourth amendment ${ }^{130}$ guarantee against physical invasions of privacy by instrumentalities of the state. The sanctity of an individual's home is also a privacy interest of "the highest order." 131 In Ohralik v. Ohio State Bar Association, the Court held that the state had a sufficient interest in the protection of a more amorphous concept of privacy to support a ban on lawyers' in-person solicitations of clients. ${ }^{132}$

In Whalen $v . R o e,{ }^{133}$ the Court considered a threat to informational privacy of the type the FCRA protects. That case dealt with New York's computerized file of the names and addresses of all recipients of specified prescription drugs. Although the Court upheld the system because it provided adequate safeguards, the Justices revealed great sensitivity to the privacy interests involved.134

The high level of constitutional protection accorded an individual's privacy interest provides a persuasive argument that the privacy interest the FCRA seeks to protect is substantial. The issue that must be addressed, therefore, is whether the constitutionally suspect sections of the FCRA directly advance that interest.

Limiting access to consumer credit information to those with commercially justifiable needs is directly related to protecting the

129 Roe v. Wade, 410 U.S. 113 (1973); Eisenstadt v. Baird, 405 U.S. 438 (1972); Griswold v, Connecticut, 381 U.S. 479 (1965).

$180 \mathrm{Katz}$ v. United States, 389 U.S. 347 (1967).

131 Carey v. Brown, 447 U.S. 455, 471 (1980).

132436 U.S. 447, 465-66 (1978).

133429 U.S. 589 (1977).

134 We are not unaware of the threat to privacy implicit in the accumulation of vast amounts of personal information in computerized data banks or other massive government files. . . Recognizing that in some circumstances that duty [to avoid unwarranted disclosures] arguably has its roots in the Constitution, nevertheless New York's statutory scheme . . . evidence[s] a proper concern with, and protection of, the individual's interest in privacy. We therefore need not, and do not, decide any question which might be presented by the unwarranted disclosure of accumulated private data - whether intentional or unintentional -or by a system that did not contain comparable security provisions.

Id. 605-06 (footnote omitted). Other courts have expressed similar concerns for informational privacy. See, e.g., Duplantier v. United States, 606 F.2d 654, 669 (5th Cir. 1979), cert. denied, 101 S. Ct. 854 (1981); Plante v. Gonzalez, 575 F.2d 1119, 1133-35 (5th Cir. 1978), cert. denied, 439 U.S. 1129 (1979).

Adequate protection of computer-stored information, however, is becoming increasingly difficult to ensure. See The Spreading Danger of Computer Crime, BusnNESS WaeK, April 20,1981, at 86, 88 (noting a "credit-profile improvement service" that gained access to the files of a subsidiary of Equifax, Inc.). This growing awareness of an increasing problem may make the Court less willing to rely on business assurances to protect the privacy interest. 
consumer's privacy interest. The Senate hearings reveal the committee's sensitivity to the privacy issue:

The central issue of privacy is the release of personal credit information to other than credit grantors. ... [T] has been overwhelming evidence that credit files on individuals can be obtained by non-credit grantors with great ease. Police agencies and federal investigators, for example, have access to most credit bureaus. ${ }^{135}$

The relationship between the prohibition on use of dated information and the individual consumer's privacy interest, however, is not so readily apparent. One argument advanced by proponents of the prohibition is that excluding dated information limits the period of the individual's life that credit reports can examine, thereby increasing the individual's control. ${ }^{136}$ This argument has merit. The period that remains open to scrutiny, however, is so long that the seven- or ten-year limitations become almost meaningless. Seven years (or longer if larger dollar amounts or a bankruptcy is involved) ${ }^{137}$ is a long period of an individual's life to be open to scrutiny. Credit information agencies may collect, maintain, and report virtually any information concerning this portion of a credit applicant's life. Permitting credit investigators this much freedom makes the concept of consumer control illusory.

Limiting use of dated information seems more closely related to the goal that only relevant information be considered when credit grantors make credit decisions. ${ }^{138}$ The relationship between this restriction and the concern for relevance, however, is similarly weak. Moreover, the FCRA contains no other limitations that advance the interest in relevance. Such ineffective legislation may fail the Central Hudson test: "[T]he restriction must directly advance the state interest involved; the regulation may not be sustained if it provides only ineffective or remote support for the government's purpose." ${ }^{189}$ The prohibition on the use of dated information probably would fail this part of the Central Hudson test because it fails to promote effectively either the privacy or the relevancy interest. Westin).

135 Hearings on S. 823, supra note 1 , at 92 (statement of Professor Alan F.

136 See supra note 125 and accompanying text.

13715 U.S.C. $\$ 1681$ c (1976 \& Supp. III 1979). See supra note 111.

138 The interest in relevance may be contained within the privacy interest.

180447 U.S. at 564. For discussion of the FCRA's failures, see Note, Fair Credit Reporting Act: The Case for Revision, 10 Lox. L.A.L. REv. 409 (1977); YAIE Note, supra note 3. 


\section{Is the regulation "more extensive than is necessary to serve [the governmental] interest"? 140}

The final part of the Central Hudson test requires that less restrictive alternatives be considered. During the Senate hearings, the concern that consumer credit reports traditionally have been made available to those with no legitimate business need-for example, the police, the Federal Bureau of Investigation, labor unions, lawyers checking on prospective jurors, and those investigating prospective husbands and sons-in-law-was identified and documented. ${ }^{141}$ The FCRA defines several permissible purposes for which credit reports may be issued. The final phrase of this section of the statute permits a credit agency to issue a report to a person it believes "has a legitimate business need for the information in connection with a business transaction involving the consumer." ${ }^{142}$ This language in effect constitutes a grant of access so broad as to render the provision almost meaningless. A less restrictive alternative that would correct the problem, however, is difficult to construct.

The restriction on the use of dated information is also minimally restrictive. ${ }^{143}$ Allowing longer time periods to remain open to credit investigators' scrutiny would be even less restrictive; it also, however, would further weaken a regulation already only marginally effective. ${ }^{144}$ One problem concerning the prohibition on dated information remains to be discussed. Most of the data covered by the time limitations in section 1681c is public record information. ${ }^{145}$ In Cox Broadcasting Corp. v. Cohn, ${ }^{146}$ the Court addressed another question concerning public record information, holding that the state could not impose sanctions for invasion of

140447 U.S. at. 566 . On its face, this test may appear to conflict with a "least restrictive alternative" test. Application of the test, however, requires that less restrictive alternatives be considered. The Court seems to say that if speech is to be restricted, the restriction must accomplish a goal that justifies imposing a limit on first amendment protection. The Court has set forth the boundaries within which permissible regulation must fall. At one end, the regulation must directly and effectively advance a substantial governmental interest. At the other end, the regulation must not restrict speech more than is necessary to accomplish this purpose.

141 See supra note 135 and accompanying text.

14215 U.S.C. $\$ 1681 \mathrm{~b}$ (1976).

143 See supra text accompanying notes 136-37.

144 Because the credit industry suggested these time periods, it may be assumed that they are not overly restrictive. See supra text accompanying note 113 .

14515 U.S.C. \$1681c (1976 \& Supp. III 1979). See supra text accompanying notes 93-94.

146420 U.S. 469 (1975). 
privacy against a television station for broadcasting a deceased rape victim's name that had already appeared in the public record.

By placing the information in the public domain on official court records, the State must be presumed to have concluded that the public interest was thereby being served. Public records by their very nature are of interest to those concerned with the administration of government, and a public benefit is performed by the reporting of the true contents of the records by the media. The freedom of the press to publish that information appears to us to be of critical importance to our type of government in which the citizenry is the final judge of the proper conduct of public business. In preserving that form of government the First and Fourteenth Amendments command nothing less than that the States may not impose sanctions on the publication of truthful information contained in official court records open to public inspection. ${ }^{147}$

This language could be read broadly to prohibit regulation of public record information in all forms of expression, including consumer reports. The situation in Cox, however, is distinguishable from one involving public record information in credit reports. First, the Court in Cox emphasized the special role of the press in reporting judicial proceedings. ${ }^{148}$ Second, the defendant in Cox was a television station providing news coverage, thus serving the public interest. $^{149}$ Third, the trial during which the victim's name was revealed was current and newsworthy. Fourth, the newspaper's speech was not commercial speech. ${ }^{180}$ None of these elements exist when reporting agencies release public record information to potential credit grantors. Because the Court in Cox stressed the role of the media in monitoring the administration of justice, ${ }^{151}$ and because commercial speech is entitled to less protection than other speech,

147 Id. 495.

148 The "Coirt said that "[ $t]$ he commission of crime, prosecutions resulting from it, and judicial proceedings arising from the prosecutions . . . are without question events of legitimate concern to the public and consequently fall within the responsibility of the press to report the operations of government." Id. 492.

149 Id. 495.

160 In Anonymous v. Dun \& Bradstreet, Inc., 3 Media L. Rep. 2376 (N.D. III. 1978), aff'd mem., 594 F.2d 867 (7th Cir. 1979), the court relied on Cox to hold that the publication of a 20-year-old criminal conviction in a consumer report did not constitute an invasion of privacy. The court, however, incorrectly characterized the credit bureau as a member of the press.

151 Consumer reporting agencies, which report public record information for purely private commercial ends, are hardly likely to be seen as playing a similarly crucial role in serving the public interest. 
the Cox rationale may not apply to the publication of consumer reports. The Court's emphasis in Cox on the information's availability in the public domain, however, suggests that it might not make this distinction. Section 1681c's restrictions on reporting dated information, therefore, might be declared unconstitutional because they prohibit dissemination of information that the state already has made available to the public.

Even if the Cox rationale is not applied in the credit reporting context, the FCRA's effectiveness in advancing the privacy interest is weakened nonetheless, because the restricted information is largely public record information. After all, a prospective creditor and a credit reporting agency are both free to research a consumer's history in the public record. The availability of information, however, is diminished by the prohibitive expenses that a single credit grantor, insurance company, or employer would incur in assembling the same information that a credit bureau is in the business of providing. In this practical sense, the protection the statute provides is real.

The invalidation of section 1681c undoubtedly would weaken the FCRA. Strict enforcement of the remaining provisions, particularly those requiring that public record information be kept up to date and those allowing consumers to challenge and to require verifcation of information, ${ }^{162}$ might help to offset the effect of such an invalidation. Some commentators, however, have suggested that stricter enforcement would not be accomplished easily. ${ }^{153}$

\section{Conclusion}

The FGRA's limitation on those who may receive consumer reports, although called into question by the Supreme Court's recent treatment of commercial speech, probably will withstand a first amendment challenge. This restriction directly and effectively advances the government's interest in protecting privacy. The prohibition on the inclusion of dated nonpublic record information also

15215 U.S.C. $\$ \$ 1681$, 1681k (1976).

153 See, e.g., Note, Fair Credit Reporting Act, 13 SuFrolx L. Rev. 63 (1979) (finding enforcement problems stemming from the tendency of courts and the Federal Trade Commission to construe the FCRA narrowly); see also Note, supra note 139 (contending that the portion of the FCRA pertaining to investigative reports is substantively inadequate to give consumers sufficient protection). This latter Note recommends amendments providing for better consumer notification and access to information to allow the consumer to check and correct his or her file prior to its release to a credit grantor. The Note also recommends substantive limits on the information that may be included in such reports. Such a revision, however, would raise additional first amendment problems. 
should survive constitutional scrutiny because it advances the government's interest in ensuring accuracy in reports. The prohibition on the use of dated public record information, on the other hand, faces a more uncertain future. Although this prohibition arguably serves the government's interest in protecting privacy by eliminating irrelevant information, it is addressed to public record information and therefore is more likely to encounter an insurmountable constitutional barrier. 